\title{
Notes
}

\section{Rethinking the Adversarial Model in Labor Relations: An Argument for Repeal of Section 8(a)(2)}

\author{
Shaun G. Clarke
}

As the United States moves into the second half-century since the National Labor Relations Act ("Act") was passed, ${ }^{3}$ the nation finds itself confronted with reports of worker dissatisfaction and declining productivity. Increasingly successful foreign economic competition adds to the urgency. ${ }^{2}$ These factors have led to a renaissance of interest in foreign, especially Japanese, management techniques. ${ }^{3}$ The Japanese model emphasizes labor-management cooperation and employee input into business decision-making. ${ }^{4}$ It is diametrically opposed to the collective bargaining model of the Act, which emphasizes adversarial interaction and requires a strict separation between management and labor.

Section 8(a)(2), ${ }^{b}$ which prohibits employers from participating in or supporting any labor organization, is the cornerstone of the Act. ${ }^{6}$ By out-

1. The National Labor Relations Act [NLRA] is actually a compendium of three separate pieces of legislation: the Wagner Act (1935), the Taft-Hartley Act (1947), and the Landrum-Griffin Act (1959). It is codified at 29 U.S.C. $\$ \S 141-187$ (1982).

2. See, e.g., Kohler, Models of Worker Participation: The Uncertain Significance of Section 8(a)(2), 27 B.C.L. REv. 499, 499 (1986).

3. Id.; Note, Participatory Management Under Sections 2(5) and 8(a)(2) of the National Labor Relations Act, 83 MicH. L. REv. 1736, 1736 (1985) [hereinafter cited as Participatory Management].

4. W. Ouchi, Theory Z: How American Business Can Meet the Japanese Challenge 36-47 (1981).

5. 29 U.S.C. $\S 158(\mathrm{a})(2)$ (1982). For the actual text of section $8(\mathrm{a})(2)$, see infra note 14 and accompanying text.

6. The primary purpose of the Act was to minimize industrial conflict by channeling it into an adversarial arms-length bargaining system. See S. REP. No. 573, 74th Cong., 1st Sess. 1 (1935) ("The first objective of the bill is to promote industrial peace."), reprinted in 2 NLRB, LEGISLATIVE HIStory of the National Labor Relations ACT, 1935, at 2300, 2300 (1949). Likewise, Senator Wagner introduced it as a bill designed to address the "sharp outbreaks of economic warfare in various parts of the country." 78 CoNG. REC. 4229, 4230 (1934), reprinted in 1 NLRB, supra, at 
lawing the formation of cooperative organizations through which employees can participate in management decision-making, section $8(\mathrm{a})(2)$ assures the separation of the parties that underlies the collective bargaining, or adversarial, model. ${ }^{7}$ Under section 8(a)(2), an employee must choose either an outside labor organization committed by law to the adversarial model, or no representation at all.

Though this model has effectively increased wages and reduced the exploitation of workers, the wall it creates between management and labor has entailed significant economic and social costs. While certain sectors of today's economy resemble the industrial landscape of 1935 for which the Act was designed, the adversarial model is anachronistic in our burgeoning service sector. In brief, the adversarial model fails to account for the vast differences in representational needs of different groups of American workers. ${ }^{8}$ Repeal of section 8(a)(2) would allow the creation of a twopronged system in which American workers could choose between the adversarial and cooperative models, depending on the needs and desires of the particular group of workers.

This Note supports the logic of the policy conclusions reached by several United States courts of appeals that refuse to enforce section 8(a)(2) where there is evidence of employee satisfaction with a challenged organization. ${ }^{9}$ However, because these decisions directly controvert the intent of

22, 24; see also I. Bernstein, Turbulent Years: A History of The AMerican Worker, 1933-1941, at 217-317 (1969); Emporium Capwell Co. v. Western Addition Community Org., 420 U.S. 50, 62 (1975) (national labor policy designed to minimize "industrial strife" by encouraging collective bargaining).

7. The term "adversarial model" is used to describe a system in which management and labor maintain a strict separation, and approach collective bargaining as competing entities with opposing interests, involved in a struggle over limited resources. Because the basic premise of this system is that the parties' interests inherently conflict, the parties rarely consider the possibility that cooperation might benefit them both. This view is reflected in NLRB v. Insurance Agents Int'l Union, 361 U.S. 477,488 (1960) ("It]he parties . . . proceed from contrary and to an extent antagonistic viewpoints and concepts of self-interest"). See generally Kohler, supra note 2, at 513-16; Note, Collective Bargaining as an Industrial System: An Argument Against Judicial Revision of Section $8(a)(2)$ of the National Labor Relations Act, 96 HARv. L. REv. 1662, 1673-80 (1983) [hereinafter cited as Collective Bargaining] (both discussing basic premises of adversarial model).

8. The difficulties in attempting to fit all work arrangements into the system of the Act are reflected in two recent cases: NLRB v. Yeshiva Univ., 444 U.S. 672 (1980), and NLRB v. Bell Aerospace Co., 416 U.S. 267 (1974). The issue in those cases was whether employees who exercised significant discretion (faculty members and buyers, respectively) should be classified as "managerial employees." This "labor-management dichotomy" is discussed infra Section V.B.1.; see also Walton, Work Innovations in the United States, Harv. Bus. REv., July-Aug. 1979, at 88, 90 ("no single culture is ideal for all businesses ... . Whatever the work culture sought, it cannot be mandated by anyone. It can only be shaped over time by a combination of things-including the techniques by which work is organized and managed.").

9. Specifically, the First, Sixth, Seventh, and Ninth Circuits have adopted the free-choice analysis. See, e.g., NLRB v. Homemaker Shops, Inc., 724 F.2d 535 (6th Cir. 1984); NLRB v. Northeastern Univ., 601 F.2d 1208 (1st Cir. 1979); Hertzka \& Knowles v. NLRB, 503 F.2d 625 (9th Cir. 1974); NLRB v. Newman-Green, Inc., 401 F.2d 1 (7th Cir. 1968); Federal Mogul Corp. v. NLRB, 394 F.2d 915 (6th Cir. 1968); Modern Plastics Corp. v. NLRB, 379 F.2d 201 (6th Cir. 1967); Coppus Eng'g Corp. v. NLRB, 240 F.2d 564 (1st Cir. 1957); Chicago Rawhide Mfg. v. NLRB, 221 F.2d 
Congress in passing the Wagner Act, the proper agent for change is Congress. Part I discusses the historical background of the Wagner Act and the purposes of section 8(a)(2). Part II illustrates various types of cooperative representation plans that are prohibited by section $8(a)(2)$. Part III traces treatment of section $8(a)(2)$ in the courts to demonstrate that judicial "free choice" analysis is fundamentally inconsistent with existing Supreme Court precedent. Part IV analyzes the competing models and examines the legislative history of the Act to illustrate additional flaws in judicial free choice analysis. Part V addresses the economic and social policy issues surrounding section 8(a)(2), and argues that workers should be allowed to choose either adversarial or cooperative representation.

\section{The Wagner Act and Section 8(a)(2)}

The Wagner Act grew out of the intellectual and social ferment that followed the Depression. It was designed to quell worker dissatisfaction and industrial strife by encouraging the development of independent labor organizations that, as representatives of a collective employee voice, could bargain on equal terms with employers. ${ }^{10}$ To the Act's framers, the greatest threat to the realization of this collective employee power was the establishment of employer-employee representation plans or "company unions." 11

These organizations differed from adversarial unions in several important respects. First, membership was confined to the employees of a single employer. Second, representatives were chosen from among the employees; there were no outside union negotiators. The employee representatives met with management to discuss not only wages, grievances, and working conditions, but also methods to improve production. Third, management usually provided secretarial help, refreshments and/or other financial assistance. Finally, the employer often, though not always, held veto power over any suggestions proferred. ${ }^{12}$

The Act's framers viewed these plans as employer puppet groups designed to frustrate the development of vigorous, independent unions. ${ }^{13}$

165 (7th Cir. 1955).

10. See, e.g., A. Cox, D. Bok \& R. Gorman, Labor Law 72 (9th ed. 1981).

11. "Company union" is the term most frequently used to describe these plans, though they went by various names such as "work councils" and "grievance committees."

12. This is only a general description. Employer involvement with, and the degree of independence of, these committees varied greatly. For an example, see NLRB v. Falk Corp., 308 U.S. 453 (1940).

13. The framers felt that company unions, by their very nature, must be employer dominated. See 79 CoNG. REC. 7565, 7569-70 (1935) (statement of Sen. Wagner), reprinted in 2 NLRB, supra note 6 , at 2321, 2333-35. Even those commentators who disagree with this proposition seem to agree that those company unions which existed prior to the NLRA were employer dominated. See Note, New Standards for Domination and Support Under Section 8(a)(2), 82 YALE L.J. 510, 514 (1973) [here- 
Section 8(a)(2) outlawed such plans. It provided that: "It shall be an unfair labor practice for an employer- to dominate or interfere with the formation or administration of any labor organization or contribute financial or other support to it."14

Company unions greatly diminished in number after passage of the Act. ${ }^{15}$ In recent decades the majority of $8(a)(2)$ claims have arisen in a different context. Section 8(a)(2) has been invoked in situations where two or more outside unions seek to become the bargaining representative for a single group of employees. An employer who feels one of the contending unions may be less demanding than the other(s) has an incentive to assist that union in gaining support from workers. The losing union(s) often invoke section $8(a)(2)$ to prohibit this practice. $^{16}$

\section{CoOperative Labor-Management ARRAngements}

Cooperative arrangements leading to greater worker input into management decision-making can take various forms, though all require emphasis on informal, personal contact between management and labor. This Part briefly describes four arrangements which have been undertaken in the United States; ${ }^{17}$ quality control circles, quality of work-life ("QWL") projects, job enrichment and redesign, and Scanlon plans. ${ }^{18}$ This Part concludes by outlining an illustrative cooperative representation plan that encompasses the goals of all these techniques and involves employees in all aspects of workplace decision-making.

inafter cited as New Standards]. It is consistent with the thesis of this Note that no one asked the employees whether they felt the organizations were employer dominated. To the framers, employees' free choice of a company union was irrelevant. This is reflected in Senator Wagner's statement that "[t]o argue that freedom of organizing for the worker must embrace the right to select a form of organization that is not free, is a contradiction in terms" (quoted in BNA, NLRB at 50: Labor Board at the Crossroads 18 (1985)).

14. National Labor Relations Act $\S 8(a)(2), 29$ U.S.C. § 158(a)(2) (1982). The section also contains a proviso explaining that, subject to rules made by the Board, "an employer shall not be prohibited from permitting employees to confer with him during working hours without loss of time or pay." Id.

15. In 1935, these organizations accounted for more than 2.5 million workers. See C. SuMMERS, H. Wellington \& A. Hyde, LABor LAW 585 (2d ed. 1982). Today they are virtually non-existent. See B. Meltzer \& S. Henderson, Labor Law 180 (3d ed. 1985).

16. See Sturgeon Elec. Co., 166 N.L.R.B. 210 (1967). These claims are easily covered by section $8(a)(1)$, which is discussed infra text accompanying notes 128-29.

17. The techniques described herein clearly violate section $8(a)(2)$ when applied in non-union settings. For an opposing view, see Participatory Management, supra note 3, at 1765. This issue is discussed infra notes 87-94 and accompanying text. Because of inconsistent treatment of the statute in the courts, however, enforcement has been less than universal. The use of these plans in union settings does not raise $8(a)(2)$ problems, although one commentator has argued that such plans may violate another section of the Act. E.g., Sockell, The Legality of Employee-Participation Programs in Unionized Firms, 37 InDus. \& LAB. Rel. Rev. 541 (1984). In either case, their success in union settings has been limited, due to the structural and cultural issues discussed infra note 140 and Section V.B.2.

18. A more detailed description of these four types of arrangements is contained in Kohler, supra note 2 , at 505-10. 
Quality control circles, which are modeled on similar Japanese arrangements, are small groups of workers and supervisory personnel, who meet on a regular basis to discuss methods of improving both the production process and the end product. ${ }^{19}$ Each circle is limited to the employees of a single department and addresses only issues of concern within that department. ${ }^{20}$ Similar techniques are often employed in QWL projects. Broadly speaking, these may involve any attempt to bring about fundamental change in workplace atmosphere and governance. ${ }^{21}$ Such projects often involve the formation of small groups of workers and managers that meet on a regular basis. They differ from quality control circles in that the immediate focus is on making the employees' work-life more fulfilling, rather than on direct product improvement. ${ }^{22}$

A particular type of QWL project may involve job enrichment and redesign through the formation of small autonomous work teams. ${ }^{23}$ Groups of five to fifteen workers are assigned responsibility for a particular aspect of production. ${ }^{24}$ Within that area the workers may decide how sub-tasks shall be performed. Thus, instead of performing a single specialized task repeatedly, a worker may have a more diverse range of tasks. The members of the team may also control ordering of production materials, budgeting, hiring, and all other activities related to their function. The goal is to increase worker satisfaction, which is believed to lead to greater productivity. ${ }^{25}$

A final technique is known as the "Scanlon Plan."28 This involves paying bonuses to both managerial and non-supervisory employees when productivity is increased. The plan is administered through a joint worker-

19. See W. Ouchi, supra note 4 , at 223.
20. Id. at 224 .
21. There is considerable disagreement about the exact definition of "quality of work-life project." See Kohler, supra note 2, at 508-09 \& nn.42-43 and sources cited therein.

22. See generally Maccoby, Helping Labor and Management Set Up a Quality-of-Worklife Program, Monthly LAB. Rev., Mar. 1984, at 28 (discussing joint AT\&T/Communications Workers of America QWL program).

23. See Kohler, supra note 2 , at 507.

24. Id.

25. The link between worker satisfaction and increased productivity is not certain, although there is evidence to support it. Some studies have found a causal connection between increased satisfaction and improved productivity. See, e.g., Cooper, Morgan, Foley \& Kaplan, Changing Employee Values: Deepening Discontent?, Harv. Bus. REv., Jan.-Feb. 1979, at 117 [hereinafter cited as Cooper Study]; Mowday, Porter \& Dubin, Unit Performance, Situational Factors, and Employee Attitudes in Spatially Separated Work Units, 12 Org. Berav. and Hum. Performance 231 (1974). Other studies have found a correlation between the two factors, although it is not certain that there is a direct causal relationship. See S. PARnes, Productiviry and THE QuAlity of Working LIfe 4 (1978); Rosenberg \& Rosenstein, Participation and Productivity: An Empirical Study, 33 INDUS. \& Lab. Rel. Rev. 355 (1980). But cf. S. Levitan \& D. Werneke, Productivity: Problems, ProsPECTS, AND POLICIES 43 (1984) (participation-productivity link deceptively simple).

26. This technique was designed by a steelworker named Joseph Scanlon in the 1930's. For a thorough description as well as a discussion of the plan's 8(a)(2) implications, see Murrmann, The Scanlon Plan Joint Committee and Section 8(a)(2), 31 LAB. L.J. 299 (1980). 
management committee made up of elected representatives from within a particular department. This committee can either reject suggestions or incorporate those which do not involve significant expenditures. Major innovations are referred to a higher level plant-wide steering committee comprised of management and worker representatives from all departments. ${ }^{27}$

These arrangements are designed to encourage a spirit of cooperation by involving employees in workplace decision-making. A full-scale cooperative representation plan could involve aspects of all four techniques. For the purposes of this Note, however, the following hypothetical plan is presented: (1) an equal number of representatives of management and labor serve staggered terms of limited duration (six to eight months), so as to involve more people directly; (2) to create some sense of continuity, one representative of each group is elected as chairperson and serves a twelve month term; (3) meetings are held on a weekly or bi-weekly basis; (4) either side may initiate discussion on any topic, including wages, hours and working conditions; (5) minor decisions are decided by discussion, and if necessary, majority vote; (6) management maintains veto power over major decisions; (7) employees are free, at any time, to withdraw in favor of adversarial representation through an outside bargaining representative. ${ }^{28}$

\section{Judicial History of Section 8(a)(2)}

Section 8(a)(2)'s current status is confused due to two difficult issues: (1) whether section $8(a)(2)$ prohibits cooperative labor-management representation plans with which employees are satisfied, and (2) how broadly the term "labor organization"29 should be read. Although the Supreme Court has issued definitive answers to both questions, several circuit courts have chosen to ignore the Supreme Court opinions, and have refused to enforce section $8(a)(2)$ where there is evidence of employee satisfaction with the challenged organization. ${ }^{30}$

27. Id. at 300-01.

28. This serves to counter-balance management's veto power over major decisions. See infra Section V.D.

29. 29 U.S.C. $\S 152(5)(1982)$. For the full text of this section, see infra text accompanying note 50.

30. E.g., cases cited supra note 9. Several commentators have argued in favor of this interpretation. See Jackson, An Alternative to Unionization and the Wholly Unorganized Shop: A Legal Basis for Sanctioning Joint Employer-Employee Committees and Increasing Employee Free Choice, 28 SYRACUSE L. Rev. 809, 833-39 (1977); Schurgin, The Limits of Organized Employer-Employee Relations in Non-Union Facilities: Some New Evidence of Flexibility, 57 CHI.[-]KENT. L. REv. 615, 617-18 (1981); New Standards, supra note 13, at 511; Participatory Management, supra note 3, at 1738. 


\section{A. Standards for Domination and Support}

\section{The Supreme Court and the Newport News Rule}

The Supreme Court has left little doubt that even a cooperative plan with which employees are satisfied is prohibited. In NLRB v. Newport News Shipbuilding $\mathbb{E}$ Dry Dock Co., ${ }^{31}$ an employer-assisted representation plan had operated to the apparent benefit and satisfaction of employees for over twelve years. The National Labor Relations Board ("Board"), found that the plan violated section 8(a)(2) and ordered that it be disestablished. ${ }^{32}$ The Fourth Circuit refused to enforce the order, stating that the Board should have considered the overwhelming evidence that the employer's motives were benevolent and that the employees were satisfied with the plan. ${ }^{33}$ The Supreme Court reversed, holding that the scheme envisioned by Congress required a strict separation between management and labor. If that separation had not been maintained, then employee satisfaction was irrelevant.

The court below agreed with the respondent that, as the Committee had operated to the apparent satisfaction of the employees . . . it would be a proper medium and one which the employer might continue to recognize for the adjustment of labor disputes. The difficulty with the position is that the provisions of the statute preclude such a disposition of the case. ${ }^{34}$

The Court further held that the employer's motive in setting up the plan and degree of involvement with it were equally irrelevant.

[I]t is immaterial . . . that any company interference in the administration of the plan had been incidental rather than fundamental and with good motives. It was for Congress to determine whether, as a matter of policy, such a plan should be permitted to continue in force. We think the statute plainly evinces a contrary purpose, and that the Board's conclusions are in accord with that purpose. ${ }^{35}$

31. 308 U.S. 241 (1939).

32. Newport News Shipbuilding \& Dry Dock Co., 8 N.L.R.B. 866 (1938). There are two types of remedies for violations of section $8(a)(2)$. If the board finds that the employer has dominated the organization, it will order that it be permanently shut down or "disestablished." In some cases where the Board has found that the employer has merely supported or interfered with the organization, it has ordered the employer to cease and desist, while allowing the organization to affiliate with an outside union and continue functioning. See, e.g., Carpenter Steel Co., 76 N.L.R.B. 670, 673-74 (1948); see also B. MELTZER \& S. Henderson, supra note 15, at 191-92.

33. The court's apparent rationale was that "[t]he purpose of the Act will not be served by destroying an organization that is without doubt the chosen representative of the great majority of the employees." 101 F.2d 841, 847 (4th Cir. 1939).

34. 308 U.S. at 251.

35. Id. 
The lesson of Newport News is clear. Section 8(a)(2) prohibits employer participation in labor organizations regardless of employee satisfaction, or employer motive and degree of involvement. ${ }^{36}$

\section{Section $8(a)(2)$ in the Circuit Courts}

The circuit courts that refuse to enforce section 8(a)(2) where there is evidence that employees are satisfied with an employer-assisted representation plan ${ }^{37}$ adopt a free choice analysis that contradicts Newport News. ${ }^{38}$ In fact, every case that pursues this analysis relies on one or more of the factors that were specifically held irrelevant in Newport News. ${ }^{39}$

In Chicago Rawhide Manufacturing Co. v. $N L R B,{ }^{40}$ the Seventh Circuit refused to enforce a Board disestablishment order despite clear employer assistance to the challenged organization. The court acknowledged the employer's involvement but held that because the involvement constituted "cooperation" rather than "support," the plan did not violate section $8(a)(2){ }^{41}$ In making this subtle distinction, ${ }^{42}$ the court relied on employee satisfaction with the plan, ${ }^{43}$ and the employer's "laudable" motives."4 Likewise, in Modern Plastics Corporation v. $N L R B,{ }^{45}$ the Sixth Circuit refused to enforce a Board disestablishment order despite clear evidence of extensive employer control of an in-house representation plan. The court ignored Newport News ${ }^{48}$ and based its holding on the fact that "the record

36. Three years after Newport News, in NLRB v. Southern Bell Tel. \& Tel. Co., 319 U.S. 50 (1943), the Supreme Court again enforced a Board disestablishment order despite undisputed evidence that the employees were satisfied and that the committee had won more than three million dollars in employer concessions. Id. at 59.

37. See supra note 9.

38. Those commentators who argue for judicial revision also rely on "free choice." See New Standards, supra note 13, at 525 ("Since employee freedom of choice is an underlying goal of the Act, the satisfaction or dissatisfaction of employees should be a controlling factor.").

39. The Board has, for the most part, been consistent with Newport News. See, e.g., Fire Alert Co., 182 N.L.R.B. 910, 917-18 (1970); Whirlpool Corp., 126 N.L.R.B. 1117, 1132-33 (1960); Carpenter Steel Co., 76 N.L.R.B. 670, 690 (1948). Occasionally, however, it has adopted the free choice analysis. See, e.g., Manuela Mfg., 143 N.L.R.B. 379, 385 (1963).

40. 221 F.2d 165 (7th Cir. 1955).

41. Id. at 167 .

42. The Board itself has traditionally found even the most seemingly trivial acts of employer "cooperation" as contributing to illegal support. See Newman-Green, Inc., 161 N.L.R.B. 1062, 1066 (1966) (emplayer provided organization with secretarial help); Nutone, Inc, 112 N.L.R.B. 1153, 1170 (1955) (employer allowed use of copying machine); Shell Oil Co. of Calif., 2 N.L.R.B. 835, 847 (1937) (employer allowed use of telephone).

43. "The membership of both Committees had been elected by the employees and there was no other organization attempting to speak for the employees. The evidence supports no conclusion other than that the Committees actually did represent the majority of employees and that the Company knew this." Chicago Rawhide, 221 F.2d at 169.

44. "The acts complained of show only laudable cooperation with the employees' organization ... the Company was not intending, by permitting this practice, to coerce or influence the employees' choice of a bargaining representative." Id. at 170 .

45. 379 F.2d 201 (6th Cir. 1967).

46. Remarkably, only one of the free choice cases even attempts to distinguish Newport News. 
contains no showing of anti union bias by the Company nor does the record contain any evidence of employee dissatisfaction." opinions rest on two of the three factors that the Supreme Court said were irrelevant. The First and Ninth Circuits have also adopted the free choice analysis, again relying on precisely the factors that the Supreme Court discounted. ${ }^{48}$ None of the free choice courts has attempted to reconcile its interpretation of the Act with Newport News. ${ }^{48}$

\section{B. Section 2(5) and the Definition of a Labor Organization}

In order to invoke section $8(a)(2)$ a party must first show that the challenged plan or committee falls within the definition of "labor organization" contained in section 2(5) of the Act. That definition is written in broad language:

The term "labor organization" means any organization of any kind, or any agency or employee representation committee or plan, in

The others, see supra note 9, ignore it altogether. The most recent free choice case cites Newport News in a footnote and states that the policy considerations which existed in 1939 have changed. See, e.g., NLRB v. Homemaker Shops, 724 F.2d 535, 547 n.12 (6th Gir. 1984). This is true, but in a question of statutory construction, the only issue which should concern the court is whether the statute has changed.

47. 379 F.2d at 204 .

48. In Hertzka \& Knowles v. NLRB, 503 F.2d 625 (9th Cir. 1974), the court refused to enforce a Board disestablishment order, stating that "[w]here a cooperative arrangement reflects a choice freely arrived at . . . we find it unobjectionable under the Act." Id. at 631. In Coppus Eng'g Corp. v. NLRB, 240 F.2d 564 (1st Gir. 1957), the court invalidated a disestablishment order, relying on employee free choice, and an absence of anti-union animus by the employer.

On the other hand, the continuing vitality of Newport News, as well as the irrelevance of majority support for a challenged organization, was recently recognized by Judge MacKinnon in Local 1814, Int. Longshoremen's Ass'n v. NLRB, 735 F.2d 1384 (D.C. Cir. 1984). He cited Newport News for the proposition that "[t]he Supreme Court has recognized that the existence of majority status is not necessarily determinative of whether employer assistance has overridden the employee's free choice." Id. at 1402.

49. Guido Calabresi and Senator Jack Davies have presented principled arguments for allowing courts to modify outdated statutes. E.g., G. CALABREsi, A Common LAw FOR THE AGE of StatUTES (1982); Davies, A Response to Statutory Obsolescence: The Nonprimacy of Statutes Act, 4 VT. L. REv. 203 (1979). For two reasons, however, their arguments are inapplicable here. First, Davies recognizes that his proposal depends on legislative authorization. Davies, supra, at 204. While Calabresi does not explicitly concede this point, he admits that without legislative authorization his proposal raises serious constitutional problems. G. CALABRESI, supra, at 116-17. Thus, he states that, "[e]xplicit and limiting legislative authorization for such a doctrine could be made a prerequisite to its use." Id. at 167. Since Congress has not authorized this practice, the arguments do not apply.

More fundamentally, however, both proposals are designed to address the problem of statutory obsolescence or "petrification." Davies, supra, at 203-04; Calabresi, The Non Primacy of Statutes Act: A Comment, 4 VT. L. REv. 247, 247 (1979). This problem occurs when statutes lay dormant for a long period of time "because lawyers acquiesce, neither lobbying nor litigating against them." Davies, supra, at 229. But the NLRA is not a statute which has lain dormant, or in which lawyers have acquiesced. The Wagner Act has been twice amended, in 1947 and 1959. Moreover, debate about the legitimacy of the Act has recurred frequently since its passage. See infra note 124, for recent scholarly critiques of the Act. In short, the Calabresi/Davies rationale for judicial revision of statutes is simply not applicable to the NLRA. 
which employees participate and which exists for the purpose, in whole or in part, of dealing with employers concerning grievances, labor disputes, wages, rates of pay, hours of employment, or conditions of work. ${ }^{30}$

Relying on this broad language, the Supreme Court has interpreted section 2(5) to encompass virtually any organization that deals with the subject matter listed therein. In NLRB v. Cabot Carbon Co., ${ }^{51}$ the Board had found that an employee committee set up to discuss grievances and working conditions with the employer constituted a labor organization under section 2(5), and that the employer's support of it therefore violated section 8(a)(2). ${ }^{62}$ The Fifth Circuit refused to enforce the Board disestablishment order. ${ }^{\mathrm{s3}}$ While recognizing that the organization was dominated by the employer, the court held that since it had not actually engaged in "bargaining with" the employer, it did not constitute a labor organization. ${ }^{34}$

The Supreme Court reversed, and reinstated the Board order. After reviewing the legislative history and analyzing the broad language employed in section 2(5), the Court stated that "Congress, by adopting the broad term 'dealing' and rejecting the more limited term 'bargaining collectively,' [in section 2(5)] did not intend that the broad term 'dealing with' should be limited to and mean only 'bargaining with' as held by the Court of Appeals."

Cabot Carbon and the explicit language of section 2(5) mandate a broad interpretation of the term "labor organization." In 1982, however, the Sixth Circuit undertook a reinterpretation in NLRB v. Streamway Div., Scott and Fetzer $\mathrm{Co}^{58}$ In that case the challenged organization was similar in nearly all respects to the Cabot Carbon committee. It dealt with the same subject matter of grievances and working conditions, and was designed to be an ongoing committee that would meet with company officials at regular intervals. ${ }^{57}$ Despite these obvious similarities, the Sixth Circuit upheld the Committee and distinguished Cabot Carbon by stating that the latter "involved a more active, ongoing association between management and employees." ${ }^{\prime \prime 8}$ The Court neglected to mention that the Streamway committee was designed as an ongoing association, and had

50. 29 U.S.C. $\S 152(5)(1982)$.

51. 360 U.S. 203 (1959).

52. 117 N.L.R.B. 1633 (1957)

53. 256 F.2d 281 (5th Cir. 1958).

54. Id. at 285.

55. 360 U.S. at 211-12.

56. 691 F.2d 288 (6th Cir. 1982).

57. Id. at 290 .

58. Id. at 294 . 
even produced a schedule for the periodic selection of representatives. The Board disestablishment order interrupted operations, and was the sole reason that the committee was not ongoing. ${ }^{59}$

Newport News and Cabot Carbon leave no doubt that section 8(a)(2) should be applied broadly and interpreted to enforce a strict separation between management and labor. The free choice decisions adduce convincing policy reasons for not applying section 8(a)(2). But as the Supreme Court stated in Newport News: "It was for Congress to determine whether, as a matter of policy, such a plan should be permitted to continue in force." ${ }^{\prime 80}$ It is now time for Congress, not the courts, to rethink the Act's original design.

\section{The System and Purposes of The Wagner Act}

The implications of the legislative history of the Wagner Act (and its subsequent amendments) ${ }^{61}$ provoke sharp controversy between defenders of collective bargaining ${ }^{62}$ and advocates of judicial free choice analysis. ${ }^{63}$ If one views "the primary concern [of the Act as] the protection of individual employee rights," ${ }^{\prime 4}$ the free choice interpretation seems compelling. But this view ignores the Act's historical purposes. The Act clearly endorsed collective bargaining and did not "attempt[ ] to strike a balance between the cooperative and adversarial approaches." 65

59. The Streamway court's section 2(5) analysis is also flawed in another respect. It begins by shifting the focus away from the definitional question of what constitutes a labor organization, and states that "our circuit is willing to reject a rigid interpretation of the statute and instead consider whether the employer's behavior fosters employee free expression and choice." Id. at 293. Thus, the court undertakes the same free choice analysis as the Chicago Rawhide court. Yet even under this analysis the plan should have been struck down. Like the Fifth Circuit opinion that was reversed in Cabot Carbon, the court concedes that the plan is employer dominated: "[T] nated by the Company. It was expressly mandated by the Company, and the Company controlled its composition and its meetings." Id. at 291. In short, the court rejects a "rigid interpretation of the statute," id at 293, and upholds the committee in the name of free choice, while simultaneously admitting that it is dominated by the employer.

60. 308 U.S. at 251.

61. See supra note 1. The Taft-Hartley amendments are discussed infra Section IV.C. The Landrum-Griffin amendments do not affect section $8(a)(2)$ analysis. 7.

62. The leading commentators are Kohler, supra note 2, and Collective Bargaining, supra note

63. See Participatory Management, supra note 3; see also New Standards, supra note 13, at 525-27 (addressing legislative history of Taft-Hartley Act only). Remarkably, the other free choice commentators make little effort to address the legislative history. See supra note 30.

64. Participatory Management, supra note 3, at 1759.

65. Id. at 1760 . 


\section{A. The Wagner Act System}

\section{Competing Theories}

Defenders of collective bargaining argue convincingly that the Act endorses a form of representation that excludes cooperative plans. ${ }^{68}$ That argument goes as follows: The framers of the Act thought that the interests of management and labor inherently conflict, and therefore that industrial conflict is inevitable. ${ }^{67}$ The Act's collective bargaining framework was designed to channel and contain this conflict within manageable boundaries. ${ }^{68}$ The parties, not the state, would defend their own interests. Critical to the maintenance of this system was a strict separation between the parties to ensure that each was fully autonomous and therefore competent to contract. ${ }^{68}$ Section $8(a)(2)$ guaranteed this separation..$^{70}$ In short, the collective bargaining model rests on the essential assumption that the interests of labor and management inherently conflict; ${ }^{71}$ two essential conditions also exist: a strict separation between the parties, and responsibility on each party for protection of its own interests.

Contesting this thesis, the free choice position argues that the framers' primary concern was not the prevention of industrial strife, but the protection of individual employee rights. ${ }^{22}$ To achieve this purpose, the argument goes, Congress chose to "strike a balance between the cooperative and adversarial approaches,"73 allowing employees to choose the method best suited to their needs. From this premise, the free choice interpretation reaches two conclusions. First, participatory arrangements should be distinguished on the basis of whether the purpose of the arrangement is representational. If an organization's purpose is not representational it does not qualify as a labor organization under section 2(5) and thus should not be subjected to section $8(a)(2)$ scrutiny. ${ }^{74}$ Second, since an important goal of federal labor legislation is "to promote cooperation between management and labor," upheld if they were freely chosen by the employees. ${ }^{78}$

66. See Kohler, supra note 2, at 518-34; Collective Bargaining, supra note 7, at 1673-80.

67. See, e.g., Kohler, supra note 2, at 515; see also R. Dahrendorf, Class and Class ConFLICT IN INDUSTRIAL SOCIETY 248-57 (1959) (developing conflicting interests thesis).

68. Collective Bargaining, supra note 7, at 1674-76.

69. Id. at 1675 .

70. See Kohler, supra note 2, at 518; Collective Bargaining, supra note 7, at 1678.

71. See supra note 67 .

72. Participatory Management, supra note 3, at 1759 ("IT]he primary concern was the protection of individual employee rights ....").

73. Id. at 1760 .

74. Id. at 1768 .

75. Id. at 1758 .

76. Id. at 1768 . 


\section{Analysis of the Free Choice Theory}

The premises as well as the conclusions of free choice theory are vulnerable. First, its premise that the Act was designed primarily to protect individual employee rights is virtually indefensible in light of both the Act's legislative history ${ }^{77}$ and its historical context. ${ }^{78}$ A still more fundamental refutation exists to characterizations of the Act as neutral, such as the aforementioned statement that "the Senate attempted to strike a balance between the cooperative and adversarial approaches." ${ }^{\text {"79 }}$ This leads to the conclusion of free choice commentators that the Act allows employees to choose between the two forms of representation. But the first section of the Act clearly states that it is designed to "encourag[e] the practice and procedure of collective bargaining."

The essentials of the collective bargaining, or adversarial model are diametrically opposed to those of the cooperative, or "integrative"81 model. The former posits an inherent conflict of interest between management and labor, ${ }^{82}$ while the latter sees their goals as compatible. ${ }^{83}$ The former requires two independent, autonomous entities ${ }^{84}$ while the latter requires integration of the parties. ${ }^{85}$ The former depends on the parties to represent their own interests, ${ }^{86}$ while the latter depends on state intervention to distinguish cooperation from coercion. Given the diametrically opposite nature of these two models, the Act cannot simultaneously encourage one while remaining neutral between the two. Because it explicitly endorses collective bargaining, the Act cannot support a neutral section $8(a)(2)$ analysis that turns on a determination of "employee free choice."

The section 2(5) analysis of the free choice position is equally vulnerable. ${ }^{87}$ It admits that Congress "express[ed] its general desire for a broad

77. See legislative history cited supra note 6. The Act's primary goal-industrial peace-was to be achieved by subjugating individual preferences in order to enhance labor's collective bargaining power. See, e.g., J.I. Case Co. v. NLRB, 321 U.S. 332, 337 (1944) (holding that individual employment contracts must yield to collective bargaining agreement); see also A. Cox, D. BoK \& $R$. Gorman, supra note 10, at 72-75; Fried, Individual and Collective Rights in Work Relations: Reflections on the Current State of Labor Law and its Prospects, 51 U. CHI. L. REv. 1012, 1027-29 (1984) (both discussing collectivist philosophy of Act).

78. The incredible level of industrial violence in the years prior to the passage of the Wagner Act is chronicled in I. BERNSTEIN, supra note 6 , at 217-317.

79. See Participatory Management, supra note 3 , at 1760.

80. 29 U.S.C. \& 151 (1982).

81. A discussion of the integrative model is contained in Kohler, supra note 2, at 516-18.

82. See supra note 67.

83. In Professor Kohler's view the integrative model actually co-opts workers into acceptance of management goals. Kohler, supra note 2, at 517. This contention is addressed infra note 129.

84. See Kohler, supra note 2, at 515; Collective Bargaining, supra note 7, at 1675.

85. See Kohler, supra note 2 , at 517 .

86. See id. at 516; Collective Bargaining, supra note 7, at 1676.

87. Participatory Management, supra note 3, at 1761-65. The flaw in this argument is its misunderstanding of the scope of section 2(5), discussed infra notes 87-94 and accompanying text. It is correct, however, in recognizing that "the Act need not be construed as necessarily precluding the 
construction of section 2(5), ${ }^{388}$ yet then proceeds to argue for a narrow construction. Specifically, it argues that only representational and not participatory arrangements should be included within section 2(5)'s definition of labor organization. ${ }^{80}$ This argument ignores both the legislative history ${ }^{80}$ and the plain language of the statute. Section 2(5) includes "employee representation committee[s] or plan[s]"91 as merely one type of labor organization within a broader definition. Under that definition "any organization of any kind" which exists "in whole or in part" to deal with employers concerning wages, hours, or conditions of work (or any of several other issues) constitutes a labor organization..$^{22}$ An organization need not be representational to deal "in part" with these issues. Even such participatory organizations as quality control circles are labor organizations, since one cannot discuss production processes and worker efficiency without discussing "conditions of work." 93 The narrow construction of section 2(5) under the free choice analysis ignores the explicitly stated intention of Congress that it be broadly construed. ${ }^{94}$

\section{B. The Purposes of the Wagner Act}

The primary concerns of the Act's framers, when viewed in light of the collective bargaining and free choice analyses, offer further support for the conclusion that the Supreme Court correctly interpreted section $\delta(a)(2)$ in Newport News.

\section{Prevention of Economic Warfare}

As discussed above, the legislative history and historical context of the Act leave no doubt that the Act's primary purpose was the prevention of

operation of labor-management committees outside the scope of section 2(5)." Participatory Management, supra note 3 , at 1763 . The framers of the Act recognized that it would be ludicrous to attempt to cut off all avenues of communication in the workplace. Hence they left such avenues open under the proviso to section $8(\mathrm{a})$ (2). Much of the legislative history that confirms this fact is misinterpreted to support this free choice commentator's thesis. See id. at 1759-61 \& nn.138-42.

88. E.g., Id. at 1764.

89. E.g., Id. at 1763 ("Despite the specific inclusion of representation committees in the Act's definition of 'labor organization,' participatory management committees do not necessarily fall within section 2(5).") (footnote omitted).

90. See S. REP. No. 573, 74th Cong., 1st Sess. 7 (1935) reprinted in 2 NLRB, supra note 6, at 2300,2306 ("The term 'labor organization' is phrased very broadly ....").

91. 29 U.S.C. $\$ 152(5)(1982)$.

92. Id. (emphasis added).

93. It is also unrealistic to suggest that groups of managers and workers will meet without at some point discussing the other broadly defined issues in section 2(5). This free choice commentator concedes the point, stating that "[i]ndividual employee grievances, or labor disputes generally, may arise tangentially." Participatory Management, supra note 3 , at 1764 . The writer adds that groups "usually avoid becoming mired in the discussion of such potentially divisive matters," but offers only one example to support this general statement. Id. at 1764 \& n.163.

94. See supra note 90 . 
industrial strife, ${ }^{95}$ or "economic warfare." Report declares that "[t]he first objective of the bill is to promote industrial peace." While this purpose does not alone refute the free choice analysis, one must consider what the framers thought was the cause of industrial strife. The free choice analysis concludes that the Act allows employees to choose between the competing adversarial and cooperative models of representation. ${ }^{88}$ Yet this competition was precisely the threat to industrial peace that the Act was designed to prevent. In discussing this problem the Senate Committee Report did not address itself merely to employer-dominated unions:

Practically 70 percent of the employer-promoted unions have sprung up since the passage of section 7(a) of the National Industrial Recovery Act. The testimony before the committtee has indicated that the active entry of some employers into a vigorous competitive race for the organization of workers is not conducive to peace in industry. ${ }^{98}$

Thus, acceptance of the free choice analysis would sanction precisely the competition that the Act was designed to prohibit. ${ }^{100}$ Section $8(a)(2)$ was specifically inserted to ensure that the Act's system of collective bargaining through outside unions would not be circumvented by allowing employers to offer an "in-house" choice. The free choice envisioned by the Act's framers was the choice among organized outside unions.

95. See supra note 6.

96. See 78 CoNG. REC. 4229 (1934) (article by Sen. Wagner), reprinted in 1 NLRB, supra note 6, at 22, 24 (discussing "sharp outbreaks of economic warfare in various parts of the country"); Unger, The Critical Legal Studies Movement, 96 HARv. L. REv. 561, 629-30 (1983) (collective bargaining designed to prevent "disruption .. . of the economic order").

97. See S. REP. No. 573, 74th Cong., 1st Sess. 1 (1935), reprinted in 2 NLRB, supra note 6, at $2300,2300$.

98. See Jackson, supra note 30 , at $812 ;$ New Standards, supra note 13 , at 511,525 . Discussion of employee preferences and majority support also dominates the free choice cases, while the industrial peace rationale is rarcly mentioned. See, e.g. Hertzka \& Knowles v. NLRB, 503 F.2d 625, 630-31 (9th Cir. 1974); Modern Plastics Corp. v. NLRB, 379 F.2d 201, 204 (6th Cir. 1967); Coppus Eng'g Corp. v. NLRB, 240 F.2d 564, 573-74 (1st Cir. 1957) (Magruder, C.J., concurring).

99. See S. REP. No. 573, 74th Cong., 1st Sess. 11 (1935), reprinted in 2 NLRB, supra note 6, at $2300,2310$.

100. Senator Wagner was also clear on this point. He recognized that "[t]he final argument advanced for company unionism is that it should be allowed to compete against trade unionism in an open field." He initially rejected this argument on the basis of its perceived inhibiting effect on collective employee action. 78 CoNG. Rec. 4229, 4230 (1934) (article by Sen. Wagner), reprinted in 1 NLRB, supra note 6 , at 22, 25. But after Senate hearings on the Bill he voiced another objection, stating that "[c]ontrary to the argument that the company union has the virtue of insuring industrial peace, we know that this open entry of employers into the field of active organization of workers promotes strife and discord." 79 CoNG. REc. 7565, 7570 (1935) (statement of Sen. Wagner), reprinted in 2 NLRB, supra note 6, at 2321, 2334. 


\section{Equalization of Bargaining Power and the Encouragement of Collective Employee Action}

A company union, whether freely chosen or not, is by definition restricted to a single employer. ${ }^{101}$ To the framers of the Act this inherent restriction on collective employee action was as great a peril as employer domination. It is beyond dispute that one of the Act's basic objectives was to increase the bargaining power of workers; the framers thought that without collective employee action to balance the strength of industry-wide employer trade associations, workers would be unable to protect their rights through collective bargaining. As Senator Wagner pointed out:

The company union has improved personal relations, group-welfare activities, discipline, and the other matters which may be handled on a local basis. But .... the wage question is a general one whose sweep embraces whole industries, or States, or even the Nation. Without wider areas of cooperation among employees there can be no protection against the nibbling tactics of the unfair employer ...102

The free choice analysis is clearly inconsistent with this objective of the Act. Whether employees are satisfied with a company union or not, it is still-by its restriction to a single employer-antithetical to the promotion of collective employee action on a regional or national scale.

\section{G. The Taft-Hartley Amendments and the Rejection of Section $8(d)(3)$}

Prior to the passage of the Taft-Hartley Amendments to the Wagner Act in 1947, Congress reconsidered the exclusive terrain it had given to the collective bargaining model. A proposed amendment stated that no finding of an unfair labor practice would be based on:

Forming or maintaining by an employer of a committee of employees and discussing with it matters of mutual interest, including grievances, wages, hours of employment, and other working conditions, if the board has not certified or the employer has not recognized a representative as their representative under Section $9 .{ }^{103}$

This proposal was strongly objected to in the House Minority Report.

101. 79 CoNG. REC. 7565,7570 (1935), reprinted in 2 NLRB, supra note 6, at 2321, 2333 (statement of Sen. Wagner) (company union "because of its intrinsic composition, it is not well suited to extend its cooperative activities beyond the bounds of a single employer unit").

102. 78 CoNG. REC. 4230 (1934), reprinted in 1 NLRB, supra note 6, at 23.

103. H.R. 3020, 80th Cong., 1st Sess. § 8(d)(3) (1947), reprinted in 1 NLRB, LegisLATIVE History OF THE LABOR-MANAGEMENT RELATIONS ACT, 1947, at 31, 56 (1948). 


\section{Legalization of Company Unions}

Section $8(d)(3)$... will resurrect and legitimate those employeerepresentation plans so familiar prior to the passage of the National Labor Relations Act. Employers by this section are authorized to establish organizations which the Supreme Court has stated are incapable of functioning as bargaining representatives of employees. ${ }^{\text {'104 }}$

These strong objections won out and section 8(d)(3) was removed from the final bill. The consideration and rejection of this amendment reflects the understanding of a later Congress that the Wagner Act did not previously allow such plans. It is a principle of statutory construction that later legislative comment on an earlier bill is considered to be an expert opinion on that bill. ${ }^{105}$ Moreover, because the architect of the 1935 Act, Senator Wagner, was still in the Senate in $1947,{ }^{108}$ the 80 th Congress can be presumed to have understood the earlier legislation. ${ }^{107}$

In Cabot Carbon the Supreme Court rejected the argument that another of the Taft-Hartley amendments had the effect of allowing cooperative plans, stating that "the conferees specifically rejected all attempts to [amend the provisions in subsection $8(a)(2)$ ] and had left its prohibitions 'unchanged.'"108 Because only eight years earlier in Newport News the Supreme Court had issued a definitive interpretation of section 8(a)(2), leaving these provisions unchanged demonstrated Congress' understanding that section $8(a)(2)$ enforces a strict separation between management and labor. ${ }^{108}$ Thus, both legislative history and Supreme Court interpretation lead to the conclusion that section $8(a)(2)$ was intended to prohibit com-

104. H.R. MinoRity RE.P. No. 245, 80th Cong., 1st Sess. 85 (1947), reprinted in 1 NLRB, supra note 103 , at 355,377 .

105. See N. Singer, Sutherland Statutory Construction $\S 49.11$ (1984) (comments on effect of earlier bill in later legislative committee report are entitled to consideration as expert opinion on previous bill).

106. Senator Wagner served in the Senate from 1927 until 1949. Congressional QuarterLY, Inc., Members of Congress Since 1789, at 158 (3d ed. 1985).

107. One free choice commentator argues that the Taft-Hartley amendments were "clearly intended to expand opportunities for labor-management cooperation." See Participatory Management, supra note 3, at 1767 . For this the author relies on a proviso to section 9(a) of the Senate Bill which stated that individual grievances could be presented to the employer and adjusted without the bargaining representative present. Id. at 1766 n.171

But this section, which is now codified at 29 U.S.C. $\S 159$ (a) (1982), also contains a second proviso: "Provided further, That the bargaining representative has been given opportunity to be present at such adjustment." Id. Thus, it presupposes that collective bargaining is in effect. Had this section actually accomplished a fundamental change in the Act-cooperative representation-it is difficult to see why it allowed the adversarial bargaining representative to be present. Rather, the section should simply be read as a matter of convenience; it ensures that employees will not have their grievance hearings held up simply because the bargaining representative is unable to be present.

108. 360 U.S. at 217.

109. See N. SiNGER, supra note $105, \S 48.18$ ("Generally the rejection of an amendment indicates that the legislature does not intend the bill to include the provisions embodied in the rejected amendment."). 
pany unions whether those unions were freely chosen by the employees or not.

\section{RETHinking THE ADVERSARIAL MODEL}

Judicial revision's inconsistency with the Act's collective bargaining system heightens the need for congressional reform. Legal literature has focused on whether the Act allows cooperative representation. ${ }^{110}$ But economists, ${ }^{111}$ politicians, ${ }^{112}$ and government officials ${ }^{113}$ have begun to address the more important question: Why is cooperative representation a good idea?

Underlying the framers' concern with controlling industrial violence was a pragmatic consideration-ensuring the economic health of the United States. As the preamble to the Act clearly states, "protection by law of the right of employees to organize and bargain collectively safeguards commerce from injury, impairment, or interruption, and promotes the flow of commerce by removing certain recognized sources of industrial strife and unrest."114

In 1935, industrial violence was undoubtedly the prime threat to the nation's economic health. But today a greater threat may lie in our weakening economic position vis-a-vis our international trade competitors. ${ }^{115}$ In the last decade the United States has moved into a "small category of countries properly defined as underdeveloping, countries whose economic development ha[s] slipped into reverse gear."116 Moreover, as one com-

110. See supra note 30 .

111. See, e.g., H. Striner, Regaining the Lead: Policies for. Economic Growth 168-72, 173-75 (1984) (arguing for necessity of cooperative rather than adversarial attitude between labor and management); Sawhill, Human Resources, in G. MILLER, Regrowing THE AMERICAN ECCNOMY 119-25 (1983) (arguing that cooperation can improve productivity and humanize work).

112. See, e.g., G. HART, A NEW DEMOCRACY 47-48 (1983) (major objective of industrial strategy must be "[t]o instill a cooperative instead of confrontational attitude in business, labor, and government").

113. Schlossberg \& Fetter, U.S. Labor Law and the Future of Labor-Management Cooperation, 3 I.ABOR LAw. 11 (1987) (United States Department of Labor undertaking study of laws, and collective bargaining traditions, that may inhibit labor-management cooperation).

114. 29 U.S.C. $\$ 151$ (1982).

115. Not only has international competition increased, but the threat of industrial violence today is much less than it was in 1935 . To begin with, there has been nothing in the last several decades to compare with the level of strife chronicled in I. BERNSTEIN, supra note 6, at 217-317. As historian Arthur Schlesinger states, in some communities labor unrest in 1935 "approached civil war." A. Schlesinger, The Age Of Roosevelt: The Coming Of The New Deal 385 (1958). Moreover, there is reason to believe that societal values have evolved to a point where the kind of massive exploitation of workers which occurred in 1935 would not be tolerated today. See infra notes 167-71 and accompanying text. This is not to suggest that exploitation of workers and resulting industrial strife is not still a concern. The suggestion is merely that the threat is not what it was in 1935 , and attempts to exploit workers can be handled on a case by case basis rather than through the wholesale prohibition on cooperation accomplished by section $8(\mathrm{a})(2)$.

116. Etzioni, The Reindustrialization of the United States of America, in F. REDBURN, T. Buss \& L. Ledebur, Revitalizing The U.S. EConomy 6, 6 (1986). 
mentator has emphasized: "America is engaged in a global economic contest of great risk ... . we are now inextricably engaged in the international economy."117 It is in this context that Congress must ask itself whether the adversarial model is still effectively serving the interests of America's workers and managers. That model posits that the interests of workers and managers inherently conflict. ${ }^{118}$ But in an era of increased economic competition from abroad, the interests of American workers and managers are quite often compatible.

Cooperative representation may have a wide variety of economic benefits. These range from breaking down the counter-productive culture of enmity that characterizes American labor relations to enhancing the quality of work-life and increasing American competitiveness in international trade. ${ }^{119}$ Some of these benefits appear almost certain, while others are more speculative. More fundamentally, however, the argument for repeal raises questions about the nature of group conflict in a pluralistic society. While the social implications of repeal cannot be fully explored here, the inquiry can be begun. ${ }^{120}$

\section{A. A Proposal for Change}

In light of Japan's economic success since World War II, the temptation is great to argue for a complete reordering of America's labor laws, and adoption of the Japanese model. But America is not Japan, and that argument fails to account for the different cultures and values of the two societies. ${ }^{121}$ America cannot adopt the Japanese model, but we can learn a lesson from it: Gooperation, where possible, is preferable to confrontation. On the issue of international competition the interests of American labor and management are compatible, perhaps identical. A growing trade deficit and a decreasing share of world markets hurts both parties. However, the domestic distribution of capital involves more antagonistic interests. The labor representation scheme for the 1990's must recognize this diversity of interests.

Moreover, the broad generalizations "labor" and "management" can be misleading. In 1935, America's economy was largely industrial. ${ }^{122}$ Today,

117. G. HART, supra note 112 , at 66 .

118. See supra note 67.

119. American economic competitiveness has been the focus of a great deal of recent media attention. See Your Next Boss May Be Japanese, NewsweEk, Feb. 2, 1987, at 42; America's Competitive Drive: Are We Losing It?, U.S. News \& WorLd ReP., Feb. 2, 1987, at 18.

120. The conclusions drawn on these issues in Kohler, supra note 2, at 548-51, are addressed infra note 129 and Section V.C.2.

121. An interesting discussion of how differing values and attitudes in American and Japanese culture affect business relationships is contained in W. OuCHI, supra, note 4, at 48-59; see also Your Next Boss May Be Japanese, supra note 119 , at 42.

122. Cf. Schrank, Are Unions an Anachronism?, Harv. Bus. Rev., Sept.-Oct. 1979, at 107; 
however, the economy and workforce are more diverse. A variety of people in our society perform a variety of jobs in areas ranging from agriculture to manufacturing, from energy to high technology and services. ${ }^{\mathbf{1 2 3}}$ Again, the labor representation scheme for the 1990's must recognize this diversity of work contexts.

Commentators from a variety of perspectives have recognized problems with the Act. ${ }^{124}$ Some have questioned its very existence. ${ }^{125}$ The prescription herein is not so radical. This Note argues for a broadening of the Act's notion of "collective empowerment."128 Workers should be given the choice between adversarial and cooperative representation. Specifically, section $8(a)(2)$ should either be repealed, or amended to clarify that it prohibits management coercion or domination, but that it does not prohibit truly cooperative representation or worker participation plans. Enforcement of the prohibition on coercive or employer-dominated plans should be handled by the courts on a case-by-case basis. ${ }^{127}$

If section $8(a)(2)$ were repealed, employer domination or coercion would still be covered under section 8(a)(1) of the Act, which makes it illegal for an employer "to interfere with, restrain, or coerce employees in

G.HART, supra note 112, at 20 (both discussing changes in workforce and economy over last several decades).

123. Id. at 23 .

124. An underlying issue in all these commentaries is the legitimacy and/or utility of the Act's goal of collective empowerment. Critical legal scholars have found fault not only with the structure of the Act itself, but also with judicial interpretation of it, and the growth of arbitration. See, e.g., J. Atleson, Values and Assumptions in American Labor Law (1983); Kennedy, Critical Labor Law Theory: A Comment, 4 INDus. REL. L.J. 503 (1981); Klare, Judicial Deradicalization of the Wagner Act and the Origins of Modern Legal Consciousness, 1937-1941, 62 MINN. L. Rev. 265 (1978); Lynd, Government Without Rights: The Labor Law Vision of Archibald Cox, 4 INDUS. REL. L.J. 483 (1981); Stone, The Post-War Paradigm in American Labor Law, 90 YALE L.J. 1509 (1981); Unger, supra note 96, at 629-32. Law and economics scholars have criticized the Act as economically inefficient. See, e.g., Epstein, A Common Law for Labor Relations: A Critique of the New Deal Labor Legislation, 92 YALE L.J. 1357 (1983); Posner, Some Economics of Labor Law, 51 U. Chi. L. Rev. 988 (1984). But see Getman \& Kohler, The Common Law, Labor Law, and Reality: A Response to Professor Epstein, 92 YALE L.J. 1415 (1983). Numerous others have also addressed the issue. See, e.g., Hyde, Democracy in Collective Bargaining, 93 YALE L.J. 793 (1984); Raskin, Elysium Lost: The Wagner Act at Fifty, 38 STan. L. Rev. 945 (1986); Sunstein, Rights, Minimal Terms, and Solidarity: A Comment, 51 U. CHI. L. REv. 1041 (1984); Weiler, Promises to Keep: Securing Workers' Rights to Self-Organization Under the NLRA, 96 HaRv. L. Rev. 1769 (1983).

125. E.g., Epstein, supra note 124, at 1357.

126. See Fried, supra note 77 , at 1028.

127. This is, in practice, the same result as that sought by judicial free choice advocates. See supra note 30 . But, of course, judicial free choice by the circuit courts directly overrides both congressional intent and the Supreme Court decisions in Newport News and Cabot Carbon. See supra Sections III-IV. Congressional action would also send a clear message of governmental endorsement of labor-management cooperation. This would be an important step in breaking down the counterproductive "adversarial culture" discussed infra Section V.B.2.; $c f$. H. STRINER, stupra note 111, at 168 ("Government, industry, and labor are inextricably bound together as joint partners in our economy. Each must be seen in a complementary relationship, not an adversarial or superior-inferior relationship."); G. HART, supra note 112, at 48 (necessity of cooperative attitude among business, government, and labor). 
the exercise of [their right to organize]." cion would clearly "interfere with" and "restrain" employees, and would thus violate section 8(a)(1). Whether Congress chooses amendment or repeal, the result will be the same. Labor and management will be free to cooperate, but oppressive employers will not be able to dominate. ${ }^{128}$

\section{B. Structural and Cultural Impediments to Cooperation}

\section{The Labor-Management Dichotomy}

To understand the social and economic implications of repealing section 8(a)(2) it is necessary to understand the current impediments to cooperation, as well as their long-term effects. The primary structural impediment is the labor-management dichotomy, the enforcement of which is the sole function of section $8(a)(2)$. The adversarial model requires a strict separation between management and labor. ${ }^{130}$ The maintenance of that separation requires clearly defined roles for each group. The Supreme

128. 29 U.S.C. $\S 158(a)(1)(1982)$.

129. In Professor Kohler's view, the adversarial model is the only acceptable representational alternative. Kohler, supra note 2 , at 550 . He portrays the cooperative model as merely a subtle tool for management subjugation of worker self-determination, and concludes that participatory techniques "can be viewed as devices that are more manipulative than democratic in intent." Id. at 547 . He bases this conclusion on the assertion that the idea of worker participation was originally advanced, in the early part of this century, on behalf of management. Id. at 516, 547. Thus, Professor Kohler's thesis rests on two assumptions: first, that cooperative techniques are designed to manipulate workers, and second, that workers will be manipulated by them.

Concerning the first assumption, it is difficult to see Professor Kohler's basis for this universal generalization about management intent. Moreover, contrary to his characterization, worker participation is not the exclusive creation of manipulative management theorists, but rather traces its roots to a number of sources, including socialist theory. See, e.g., Strauss \& Rosenstein, Workers Participation: A Critical View, 9 Indus. Rel. 197, 201-02 (1970). Even among the "human relationist" school, acceptance by workers of management's goals was to be achieved by satisfying workers' needs, not by subjugating them. T. Kochan, Collective Bargaining and Industrial Relations 10-11 (1980) (human relationists concerned with "assuring that the goals of employees were also being achieved"). Finally, even if early advocates of participation had intended to use these devices to manipulate, it does not follow that workers and managers who today are truly interested in cooperation should forever be restricted from using them.

Professor Kohler's second assumption-that workers will be manipulated-presents an unflattering vision of workers' ability to identify and assert their own interests. His statement that "integrative devices may help to promote the belief in and acceptance of managerial authority amongst employees by making them feel as if they have a share in its exercise," Kohler, supra note 2, at 547, suggests that employees are incapable of recognizing that they are being manipulated. Yet, Professors Getman, Goldberg \& Herman have demonstrated in their empirical work that workers are neither unsophisticated about their right to unionize, nor easily manipulated by management. See, e.g., J. GETMAN, S. Goldberg \& S. Herman, Union Representation Elections: Law and Reality 140-41 (1976) (discussing general ineffectiveness of employer attempts to influence unionization votes).

Professor Kohler frames the issue as if repeal of section 8(a)(2) will mean the end of collective bargaining. Kohler, supra note 2, at 545-51. But if, as the evidence suggests, workers can recognize manipulation and exercise an informed choice, then repeal will allow workers to choose either adversarial or cooperative representation. Moreover, employer domination or coercion can be handled by the courts on a case-by-case basis. Thus, repeal is not an "all or nothing" choice between the two models. Rather, it would leave that choice to the workers.

130. See Collective Bargaining, supra note 7, at 1674-76. 
Court subscribed to this dichotomy and endorsed the Board's test of managerial status in NLRB v. Bell Aerospace. ${ }^{131}$ Under that test, managers "formulate and effectuate management policies by expressing and making operative decisions of their employer."1s2 Thus, the role of the manager is to make the discretionary decisions that set company policies. These decisions fall outside the realm of labor's role in the dichotomy. Section $8(a)(2)$ reinforces the dichotomy by outlawing the formation of cooperative organizations through which employees can participate in discretionary decision-making.

\section{The Adversarial Culture of American Labor Relations}

The ugly history which gave rise to the Wagner Act, ${ }^{133}$ combined with the enforced labor-management dichotomy, has resulted in the development of an adversarial culture in American labor-management relations. Justice Douglas' stirring dissent in Packard Motor Co. v. NLRB ${ }^{134}$ typifies this attitude. Lamenting a breakdown in the dichotomy, he warned that "management and labor will become more of a solid phalanx than separate factions in warring camps." "1ss As one commentator notes, United States labor history has been marked by "a trade unionism that was militant in organizing industry and establishing an adversary position in that work setting." ${ }^{\text {138 }}$ This statement must be qualified by the recognition that employers bear equal responsibility for this traditional adversarial posture. Moreover, in the climate of the 1930's an adversarial posture was necessary to solidify worker support.

This culture is as important as the structure of the Act in inhibiting the growth of labor-management cooperation. ${ }^{137}$ Unions and management need not remain hostile. Two parties can vigorously represent opposing interests without the deep-seated enmity that characterizes the American labor scene. Labor-management cooperation can occur both in and out of the collective bargaining context. Nonetheless, without repeal of section $8(a)(2)$-and a softening of the labor-management dichotomy-it is unlikely that the "warring camps" will be able to break out of their counterproductive relationship. The structure of the Act enforces an adversarial framework. The strict separation of the parties, embodied in the labor-

131. 416 U.S. 267 (1974).

132. Id. at 286 (quoting Palace Laundry Dry Cleaning, 75 N.L.R.B. 320, 323 n.4 (1947)).

133. See A. SCHLESINGER, supra note 115, at 385-406; I. BERNSTEIN, supra note 6, at 217-317.

134. 330 U.S. 485 (1947).

135. Id. at 494 (Douglas, J., dissenting). This dissent became the intellectual underpinning for Bell Aerospace.

136. Schrank, supra note 122 , at 110 .

137. For a source which discusses the effects of this culture and the prospects for change under current law, see generally Schlossberg \& Fetter, supra note 113 . 
management dichotomy, focuses the conflict; the intricate regulations and formal processes of collective bargaining create a highly formalized milieu in which the parties interact. Section 8(a)(2)'s restriction on cooperative dealing further inhibits communication.

Modern economic conditions put a premium on labor-management cooperation. Between 1950 and 1983, the United States dropped from first to last in relative productivity among the twelve countries indexed by the Department of Labor. ${ }^{138}$ At the same time, market competition from these nations, and with it the U.S. annual trade deficit, has dramatically increased. ${ }^{139}$ Both labor and management have an interest in addressing these economic realities. But for cooperation to be effective-in or out of the union setting-the statutorily reinforced culture of distrust must be broken down. ${ }^{140}$

Even where a union has been certified, an employer is only required to bargain over a limited number of mandatory bargaining subjects. ${ }^{141} \mathrm{Be}-$ cause of the adversarial nature of the interaction, the employer is unlikely to be willing to discuss other "permissive" subjects that concern workers. In a cooperative plan both parties have entered the relationship voluntarily, and thus both have an interest in seeing it maintained. If employers are not sensitive to workers' concerns, the workers can opt-out in favor of collective bargaining. In this context, an employer is likely to consider all areas of employee concerns, rather than begrudgingly discussing only those issues over which the law mandates dialogue.

Legislative revision of section $8(a)(2)$ will send a clear message to both labor and management that Congress is willing to endorse cooperation as part of a new economic program. This is a benefit which isolated judicial revision can never produce. ${ }^{142}$ Significant steps toward a more constructive relationship between unions and management have already begun. ${ }^{143}$ The

138. U.S. DeP'T of LABOR, HandBook of Labor Statistics 415, 431 (June 1985). While productivity in the United States has increased slightly in the past three years, the rate of growth has not kept pace with that in other countries. See Dean, Boissevain \& Thomas, Productivity and Labor Costs Trends in Manufacturing, 12 Countries, Monthly LAB. Rev., Mar. 1986, at 3, 4.

139. In 1985, the United States imported approximately $\$ 360$ billion worth of goods, while exporting just over $\$ 200$ billion worth. See, e.g., U.S. Dep't of Commerce Index, MonTHLy Lab. REv., April 1986, at 8.

140. While cooperative programs in the union context may not violate section $8(a)(2)$, attempts at cooperation have fit awkwardly in the adversarial setting and have met with mixed success. For widespread attempts at cooperation in the collective bargaining context to succeed, the adversarial culture must be undone. See Kohler, supra note 2, at 518 (discussing "uncomfortable . . . fit" of participative techniques in collective bargaining context); Goodman, Realities of Improving the Quality of Work Life, 31 LAB. L.J. 487, 491 (1980) ("conflict between the coooperative mode of QWL and the adversary mode of traditional collective bargaining can limit the viability of the QWL effort.").

141. See NLRB v. Wooster Div. of Borg-Warner Corp., 356 U.S. 342, 349 (1958) (adopting mandatory-permissive distinction).

142. The importance of this symbolic message is discussed supra note 127 .

143. See, e.g., Schlossberg \& Fetter, supra note 113, at 14-17 ("certain segments of the labormanagement community are becoming "partners in the enterprise." "). 
worker participation plans undertaken by the United Auto Workers in cooperation with Ford Motor Company, for example, have not only resulted in greater employee satisfaction, but have also increased earnings to employees through greater productivity. ${ }^{\mathbf{1 1 4} 4}$ While these isolated attempts at cooperation in the collective bargaining context are a step in the right direction, they are not enough. ${ }^{145}$ Confrontational, not cooperative mindsets still generally prevail. ${ }^{148}$ Even if the formation of cooperative representation plans ultimately does not prove fruitful, repealing section $8(\mathrm{a})(2)$ would help to break down this adversarial culture by opening lines of communication between management and labor.

\section{Economic and Social Implications of Repeal}

\section{Economic Implications}

\section{a. Changes in the American Workforce}

Both the American economy and workforce have changed immensely in the past several decades. ${ }^{147}$ Most significantly, growth in the service sector has resulted in an increase in white-collar workers from twenty-six percent of the total workforce at the turn of the century ${ }^{148}$ to seventy-two percent in $1984 .{ }^{149}$ Over the past twenty years the fastest growth has been in high-skill service sector jobs. ${ }^{180}$ This change from a primarily industrial

144. Id. at 16.

145. See supra note 140 .

146. See, e.g., L. Rukeyser, What's AheAd For the Economy 154-55 (1983); Schlossberg \& Fetter, supra note 113, at 18 ("The history of labor relations in this country has been, and to a large degree continues to be, characterized by confrontation.").

147. Today's workforce is better educated, contains a higher proportion of female workers, and exhibits a substantially more assertive attitude in expressing dissatisfaction with working conditions. See, e.g., G. HART, supra note 112, at 23 (discussing increase in percentage of women, and other general changes in workforce); Cooper Study, supra note 25, at 118 (workers are "beginning to overtly articulate their needs for achievement, recognition, and job challenge"); Ginzberg, The Professionalization of the U.S. Labor Force, SCIENTIFIC AMERICAN, Mar. 1979, at 48 (discussing higher level of education among post WW II workers); Mills, Human Resources in the 1980's, Harv. Bus. REv., July-Aug. 1979, at 154, 156 (discussing increase in percentage of college educated women in workforce). The trend toward assertiveness was visible as far back as 1973 when a special task force found that younger workers, "inability to control the pace and style of work are cause for a resentment which they, unlike older workers, do not repress." SPECIAL TASK ForCE TO THE SECRETARY of Health, Educ. ANd Welfare, 93rd Cong., 1st Sess., Report on Work in America 16 (1973) [hereinafter cited as SPECIAL TASK FoRCE].

148. Schrank, supra note 122 , at 113.

149. Kutscher \& Personick, Deindustrialization and the Shift to Services, Monthly LAB. Rev., June 1986, at 3,5. One economist has predicted that over $90 \%$ of the workforce will be in service sector jobs by the year 2000. Careers for the Long Haul, NewsweEk ON CAMpus, Sept. 1986, at 15, 17.

150. Contrary to popular myth, service sector jobs are not primarily low-skill, low-wage jobs. The definition of services under our national accounting system includes wholesale and retail trade, communications, accounting, legal counsel, banking, architecture, engineering, hotels and restaurants, and education. See, e.g., Shelp \& Shelp, Services as an Industrial Policy Issue, in F. REDBuRN, T. Buss \& L. LEDEBUR, supra note 116, at 29, 30-31; Ginzberg \& Vojta, The Service Sector of the U.S. 
to a primarily service economy is likely to prove permanent. Yet the Act, by its own terms, was designed to deal with "industrial strife."151 It is difficult to justify restricting representation to a form that was designed for industrial workers, in an economy where three of four jobs are nonindustrial.

The change in workforce composition has been accompanied by a broadening of workers' job related concerns. Perhaps because of the success of unions in securing higher wages, workers have expanded their concerns into other areas as well. While wages and other "bread and butter" issues may still predominate, ${ }^{\mathbf{1 6 2}}$ there is evidence that workers are also concerned today with the quality of life in the work environment. ${ }^{163}$ This evidence has considerable import for the adversarial model. As Senator Wagner repeatedly emphasized, the adversarial model's solution to the problem of substandard wages would come at some cost to the quality of work life. ${ }^{184}$ When he argued for the inclusion of section $8(\mathrm{a})(2)$, he recognized that company unions had improved employer-employee relationships. ${ }^{165}$ Today even Professor Kohler - a vigorous opponent of repeal-concedes that the cooperative model "has undoubtedly served both to make work less oppressive and the atmosphere of the workplace more humane."156

Workers may spend a quarter to a third of their adult lives on the job. Thus, the quality of work-life is an important issue. As Judge Wisdom has observed, section $8(a)(2)$ "erects an iron curtain between employer and employees . . . preventing the development of a decent, honest, constructive, relationship between management and labor."157 Certainly, there is an advantage to allowing workers and management to cooperate in working out their differences, rather than forcing them to communicate, if at all, through the formalized and adversarial process of collective bargaining. As Professor Fried points out, section 8(a)(2) imposes "a flat requirement of a particular kind of association, a kind of association that in some circumstances none of the parties involved may prefer."158

\footnotetext{
Economy, SCIENTtFIC AMERICAN, Mar. 1981, at 48-55.

151. 29 U.S.C. $§ 151$ (1982).

152. Wage issues remain prominent, for example, on the feminist agenda. See County of Washington v. Gunther, 452 U.S. 161 (1981); American Nurses Assoc. v. Illinois, 783 F.2d 716 (7th Cir. 1986); AFSCME v. Washington, 770 F.2d 1401 (9th Cir. 1985) (Title VII claims alleging sex-based wage discrimination).

153. See, e.g., Cooper Study, supra note 25, at 118; SPECIAE TASk Force, supra note 147, at 16.

154. See stipra text accompanying note 102 .

155. 78 CoNG. REC. 4229 , 4230 (1934), reprinted in 1 NLRB, supra note 6, at 23 ("The company union has improved personal relations ....").

156. Kohler, supra note 2, at 547.

157. NLRB v. Walton Mfg. Co., 289 F.2d 177, 182 (5th Cir. 1961) (Wisdom, J., dissenting).

158. Fried, supra note 77 , at 1027 .
} 


\section{b. Participation and Productivity}

As discussed earlier, the United States faces significant economic competition. ${ }^{169}$ Yet our productivity growth has fallen dramatically in relation to our competitors. While the results are not conclusive, there is evidence that worker participation in management enhances productivity in several ways. ${ }^{100}$ First, worker participation involves larger numbers of people in thinking about, identifying, and solving problems. ${ }^{161}$ The labormanagement dichotomy, by restricting decisionmaking to managers, ignores-and via section 8(a)(2) outlaws-the creative and intellectual contributions of workers. Second, by increasing worker satisfaction, participation may also improve individual productivity. ${ }^{\mathbf{1 6 2}}$

Third, worker participation may increase productivity by enhancing cooperation among actors in the service sector workplace. The labormanagement dichotomy recognizes only the type of work arrangement that has traditionally inhered in industrial manufacturing-a hierarchical structure in which management exercises complete control over the actions and activities of labor. But as one commentator has noted, "[ $t$ ]he demarcation of class lines in service sector workplaces is never as clear as it was in the old factory."183 It is difficult to draw a clear line as to who "formulates and effectuates management policies" in the service context. The effective functioning of a service sector workplace requires coordination among the discretionary decisions made by actors at various levels. Because section $8(a)(2)$ inhibits cooperation in the service sector workplace, repeal may enhance productivity.

\section{Social Implications}

As one commentator has put the issue, the argument over section 8(a)(2) involves a basic choice about societal governance. ${ }^{164}$ Critical legal scholars echo this theme. ${ }^{165}$ When one views worker-manager relations in

159. See supra notes 138-39 and accompanying text. Our trade deficit with Japan alone was $\$ 56.8$ billion in 1986. N.Y. Times, Mar. 8, 1987, at F2, col. 5. This imbalance has caused considerable tension between the two countries. Farnsworth, U.S. Resentment Grows on Japan Trade Barriers, N.Y. Times, Mar. 30, 1987, at D1, col. 1; Chira, Some in Japan Feel U.S. Is Using It as Scapegoat, Id.

160. See supra note 25; see also Goodman, supra note 140, at 489.

161. Rosenberg \& Rosenstein, supra note 25 , at 356.

162. See supra note 25; see also Goodman, supra note 140, at 489.

163. Schrank, supra note 122 , at 113 .

164. Kohler, supra note 2, at 533, 549-51. Of course, this Note disputes Professor Kohler's conclusion that the preservation of democracy requires enforcement of section 8(a)(2).

165. See Stone, supra note 124, at 1511-14; Unger, supra note 96, at 630; Wachtel, Class Consciousness and Stratification in the Labor Process, in R. EDWARDS, M. REICH \& D. GORDON, LABOR MARKeT SEGMENTATION (1975) (noting worker frustration due to segmentation of work processes that prevents worker control); see also J. ATLESON, VALUES AND ASSUMPTIONS IN AMERICAN LABOR LAW (1983) (untested assumptions about economic system and about actors within that 
terms of class struggle within a pluralistic society, fundamental questions about our institutions of self-rule arise. How, ideally, would we as a society like to see differing groups resolve their differences? Do we want to compel them to act as adversaries and to statutorily restrict them from resolving their differences through cooperation? Do we want to enforce their separation rather than allowing their integration?

Relative to other group struggles in American society, manager-worker relations have lagged far behind. Whereas race and gender relations have advanced markedly in the last half-century, advances in labor relations have been inhibited by the Act's restriction on cooperation. The militant posture of labor in the early 1930's unquestionably played an essential role in securing passage of the Act and the resulting workers' rights. ${ }^{188}$ In the context of near revolutionary industrial violence which preceded the Act's passage, the adversarial model was not only appropriate, but was probably the only reasonable representational alternative.

Yet, accepting the validity of the Act's premises in 1935 does not confirm that present social conditions still justify section $8(a)(2)$ 's restriction on cooperative labor-management relations. To begin, societal values have changed. ${ }^{167}$ Whereas American society tolerated worker exploitation in 1935 , it also countenanced legally enforced segregation until the 1960's, as well as gender restricted franchise earlier in the century. One cannot conclude that our society would accept these injustices today. But the answer need not rest on analogy alone. Societal recognition of the basic human right to decent wages and working conditions is reflected in such statutes as the Fair Labor Standards Act, ${ }^{\mathbf{1 6 8}}$ the Occupational Safety and Health Act, ${ }^{169}$ and the Employee Retirement Income Security Act, ${ }^{170}$ as well as

system underlie many labor law decisions).

166. Similarly, the fear engendered in white America by radical black groups was important in securing rights for black people in the early decades of the civil rights movement. This point was raised recently during the planning for the opening of a Black Panther Archives. In the words of Kathleen Cleaver, a former Black Panther leader: "The willingness of the white establishment to accept black politicians who already were willing to work within the system was accelerated and encouraged by activities of a very, very revolutionary group like the Black Panthers." New Haven Register, Oct. 19, 1986, at A13, col. 1.

167. See Fried, supra note 77, at 1031 ("[N]umerous progressive employers have elaborate personnel schemes that provide protections and benefits analogous to those offered in unionized settings.").

168. 29 U.S.C. $\S \S 201-219$ (1982 and Supp. III 1985).

169. 29 U.S.C. $\S \S 651-670$ (1982 and Supp. III 1985).

170. 29 U.S.C. $\S \S 1001-1453$ (1982 and Supp. II 1984; Supp. III 1985). 
common law developments such as the "wrongful discharge" tort ${ }^{171}$ and the demise of the contract at will. ${ }^{172}$

The interests of labor and management will sometimes, perhaps often, diverge. But does this justify forcing them to interact in a static, formal, adversarial relationship? In virtually all other group struggles within our society, we have chosen to let the struggle evolve. While these struggles continue, the relationships have changed-as has the tenor of each conflict. Why then have we locked labor-management relations into an adversarial framework for the past half-century? Although the answers lie beyond the scope of this inquiry, these questions are relevant to the section $8(a)(2)$ debate, and involve issues that are fundamental to the character of American society. ${ }^{173}$

\section{The Future of the American Union}

A final point to be considered is the contention that repeal of section 8(a)(2) will mean the end of the American union. This position ignores the strong commitment to unionism in the industrial and public sectors, however, and underestimates the importance of a union presence to the effectiveness of cooperative representation. Adversarial unionism will still play an important role in a two-pronged labor representation scheme.

Although the adversarial model does not serve the needs of all American workers, it can serve the needs of some. Many policy reasons that favor cooperative plans apply with particular force to the service sector. Unions originated, and continue to have success, among industrial workers. While the unionized sector of the non-agricultural workforce declined from a zenith of forty-one percent in $1947^{174}$ to less than twenty percent in $1982,{ }^{175}$ the commitment to unionism within the industrial sector has not flagged. Likewise, unions have had considerable success in organizing public sector employees. ${ }^{178}$ There is nothing to suggest that repeal of sec-

171. See generally Note, Protecting at Will Employees Against Wrongful Discharge: The Duty To Terminate Only in Good Faith, 93 HARv. L. REv. 1816, 1818-24 (1980) (discussing recent developments limiting employment at will doctrine). For specific examples, see Tameny v. Atlantic Richfield Co., 27 Cal. 3d 167, 610 P.2d 1330, 164 Cal. Rptr. 839 (1980); Kelsay v. Motorola, Inc., 74 Ill. 2d 172, 384 N.E.2d 353 (1978); Frampton v. Central Ind. Gas Co., 260 Ind. 249, 297 N.E.2d 425 (1973); see also Fortune v. National Cash Register Co., 373 Mass. 96, 364 N.E.2d 1251 (1977) (tort recognized but not developed); Geary v. United States Steel, 456 Pa. 171, 319 A.2d 174 (1974) (tort recognized but not applied).

172. At least one commentator has criticized this development. See Epstein, In Defense of the Contract at Will, 51 U. CHI. L. REv. 947 (1984).

173. Kurt Vonnegut offers an interesting (and disturbing) fictional account of a society where workers and managers are entirely segregated. See K. Vonnegut, Player Piano (1952).

174. Schrank, supra note 122 , at 113 .

175. Bureau of the Census, U.S. Dep't. of Commerce, Statistical abstract of the United States 408 (107th ed. 1987).

176. See, e.g., Noble, Public-Sector Unions Are Labor's Darlings, N.Y. Times, Mar. 8, 1987, at E4, col. 1. 
tion $8(a)(2)$ will lessen the commitment to unionism among these workers. ${ }^{177}$

Moreover, cooperative representation would be considerably less effective without a vigorous union presence. Just as worker and manager interests do not always conflict, neither do they always coincide. There will undoubtedly continue to be situations where an adversarial presence in the workplace is necessary to protect worker interests. The cooperative ideal presented in Part II of this Note depends on workers' freedom to withdraw in favor of collective bargaining. This is essential to counter-balance management's veto power over major decisions. A convincing argument that cooperative plans would signal the end of unions would significantly weaken the argument for repeal.

Opponents of repeal might argue that the proposal unfairly relies on unions for enforcement, while at the same time undermining their strength. There are two answers to this objection. First, it is not clear that repeal will weaken unions. Cooperative plans are most likely to be implemented in the service sector. Unions have had little success in organizing service sector workers. Even without repeal, these workers are not likely to adopt collective bargaining. ${ }^{178}$ Second, the ultimate goal of a labor relations scheme is to benefit workers. Unions are one-thus far the primary-instrument through which that task has been accomplished. If a two-pronged (adversarial and cooperative) system creates an overall benefit to workers, it should not matter that it might slightly weaken the independent strength of one of its instruments. Repeal of section $8(a)(2)$ will not mean an end to collective bargaining. Instead, it will lead to a more sophisticated two-pronged system designed to meet the needs of the 1990's workforce.

\section{ConClusion}

The adversarial model of collective bargaining has been effective within its sphere. But changes in the workforce, the economy, and society limit that sphere. The economic and societal conditions of the 1990's will require the adoption of diverse types of representational forms to meet the

177. The actual number of industrial jobs has not declined in the last 25 years. Rather, the decline in the percentage of the workforce in the industrial sector has been relative to the growth of service sector jobs. See, e.g., Kutscher \& Personick, supra note 149, at 4 .

178. The difficulty in organizing service sector workers reflects a difference in attitudes between that group and industrial workers. The AFL-CIO's chief organizer, Charles McDonald has noted that industrial workers tend to prefer a "tough" or adversarial image in dealing with employers. Yet, it is precisely this image which hampers organization of service sector workers, who tend to view unions as too confrontational. Noble, Labor's New Chief Organizer, N.Y. Times, Oct. 21, 1986, at B6, col. 3; see also, Schrank, supra note 122, at 112 (discussing difference in attitudes between bluecollar and service sector workers). 
needs of different groups of American workers. While judicial efforts to revise section $8(a)(2)$ can accomplish this change, these decisions directly override the intent of Congress in passing the National Labor Relations Act. The proper agent for change is Congress, which should repeal section $8(\mathrm{a})(2)$ and legalize cooperative representation. 